\title{
Recent advances in passive cooling methods for photovoltaic performance enhancement
}

\author{
Emy Zairah Ahmad ${ }^{1}$, Kamaruzzaman Sopian², Hasila Jarimi ${ }^{3}$, Ahmad Fazlizan ${ }^{4}$, Abdelnaser Elbreki', \\ Ag Sufiyan Abd Hamid ${ }^{6}$, Shirin Rostami ${ }^{7}$, Adnan Ibrahim ${ }^{8}$ \\ ${ }^{1}$ Faculty of Electric and Electronic Engineering Technology, Universiti Teknikal Malaysia Melaka, Malaysia \\ ${ }^{1,2,3,4,7,8}$ Solar Energy Research Institute, Universiti Kebangsaan Malaysia, Malaysia \\ ${ }^{5}$ College of Electrical and Electronics Technology, Libya \\ ${ }^{6}$ Faculty of Science and Natural Resources, Universiti Malaysia Sabah, Malaysia
}

\begin{abstract}
Article Info
Article history:

Received Mar 27, 2020

Revised Jun 1, 2020

Accepted Aug 5, 2020

\section{Keywords:}

Efficiency improvement Module temperature Passive cooling Photovoltaic module Temperature coefficient

ABSTRACT

The electrical output performance of photovoltaic (PV) modules are sensitive to temperature variations and the intensity of solar irradiance under prolonged exposure. Only $20 \%$ of solar irradiance is converted into useful electricity, and the remaining are dissipated as heat which in turns increases the module operating temperature. The increase in module operating temperature has an adverse impact on the open-circuit voltage (Voc), which results in the power conversion efficiency reduction and irreversible cell degradation rate. Hence, proper cooling methods are essential to maintain the module operating temperature within the standard test conditions (STC). This paper presents an overview of passive cooling methods for its feasibility and economic viability in comparison with active cooling. Three different passive cooling approaches are considered, namely phase change material (PCM), fin heat sink, and radiative cooling covering the discussions on the achieved cooling efficiency. The understanding of the above-mentioned state-of-the-art cooling technologies is vital for further modifications of existing PV modules to improve the efficiency of electrical output.
\end{abstract}

This is an open access article under the CC BY-SA license.

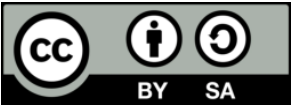

\section{Corresponding Author:}

Adnan Ibrahim,

Solar Energy Research Institute, Universiti Kebangsaan Malaysia, 43600 Bangi, Malaysia.

Email: iadnan@ukm.edu.my

\section{INTRODUCTION}

Photovoltaic (PV) modules convert sunlight into electricity with the aid of semiconductor material through the photovoltaic effect. However, the output performance of the PV module significantly depends on several external factors such as solar irradiance and ambient temperature, causing the reduction of electrical output and its life span [1]. The main problem which limits the electrical performances of PV technology is the overheating of the PV module. The literature has shown that only $20 \%$ of the absorbed solar radiation is converted into useful electricity, and the remaining part of solar radiation is dissipated as heat [2]. The temperature increment of the PV module can reach values up to $80^{\circ} \mathrm{C}$. Based on the previous study, for every $1{ }^{\circ} \mathrm{C}$ increase in module temperature causes the decrease of output power by $0.4-0.5 \%$ depends upon the PV cell technology used [3-5]. For this reason, there is a need to understand the proper cooling techniques to solve the temperature problem. 
Several cooling techniques have been investigated to remove the heat generated by the PV module and hence lowering its temperature. The temperature regulation of PV modules can be classified by two general methods, namely, passive and active approach. The active cooling requires additional components (pump or blower) for the flow circulation of the coolant. The main issues related to such a method are their applicability and economic viability [6]. Recently, the following active cooling methods have been investigated by several researchers such as buried heat exchanger [7-9], pulsating heat pipe [10, 11], water cooling [12-14], and airflow cooling [15-18]. Despite a significant reduction of module operating temperature, the overall initial investment cost is still a considerable concern.

On the other hand, several researchers have worked on a passive cooling approach. This approach is based on the natural convection principle utilising the ambient airflow to reduce the PV panel temperature. Passive cooling methods are more attractive because it requires no additional input power. Currently, the following passive cooling methods have been investigated such as phase change material (PCM) [19-26], passive fin heat sink [27-33] and radiative cooling [34-36].

The understanding of the above-mentioned state-of-the-art cooling techniques is crucial to improve the efficiency of electrical output. Several researchers have conducted extensive reviews on various cooling methodologies, but to the best of our knowledge, there is limited review focusing only on passive cooling approaches [37, 38]. Setting it apart from the aforementioned papers, the focus of this paper is to review the passive cooling methods for PV module that have been reported in the literature over the past two years. The article is structured as follows. First, the parameters that influence the performance of a PV module, including the derating factors, are discussed. Second, the paper details the literature conducted over the past two years on the passive cooling method for PV modules which includes cooling with phase change materials fins heat sinks and radiative cooling. Finally, the comparison between the aforementioned passive cooling methods is discussed. From the comparison, the most promising approach is suggested and elaborated at the end of this paper.

\section{PERFORMANCE PARAMETERS}

A typical crystalline silicon PV module consists of several interconnected cells (usually 36 cells are connected in series) encapsulated into a long-lasting and stable unit. The primary purposes of the PV module encapsulation are to protect the electrically connected solar module from damage due to uncontrolled environmental factors such as humidity, dust, shading, and others [39]. The module lifetimes and warranties of PV modules are typically about 25 years, indicating the encapsulation robustness [40]. However, an undesirable impact of the encapsulation is that it contains the heat flow into and out of the module lead to an elevated module operating temperature [41]. The module operating temperature is defined by the energy balance equation between heat generated by the sun and heat loss from the module to the surroundings [42]. The electrical output of the PV module under real operating conditions differs from Standard Test Conditions (STC), generally measured at $25^{\circ} \mathrm{C}$ and $1000 \mathrm{~W} / \mathrm{m}^{2}$. Based on the temperature dependence of the opencircuit voltage, a reduction in the power conversion efficiency by $0.2-0.5 \%$ is observed with an increment of $1{ }^{\circ} \mathrm{C}$ [37]. The increase in module temperature causes a linear reduction of the output power [43-45]. This value denoted as a temperature coefficient and can usually be found in the manufacturer datasheet.

The performance of different module technology depends significantly on environmental conditions such as the intensity of solar irradiation, wind speed, inclination angle, and the accumulation of dust [45]. Figure 1 shows the thermal images of two different module technologies recorded under the influence of the same environmental conditions. The recorded module temperature is higher in monocrystalline silicon $\left(44.59^{\circ} \mathrm{C}\right)$ as compared to thin-film technology $\left(42.88^{\circ} \mathrm{C}\right)$. The monocrystalline module performs poorly at elevated temperature due to the issue (but not limited to) of front-to-back contact interconnection. Unlike the thin-film PV module, that is a monolithically single unit and does not require individual interconnection, hence demonstrates better performance at higher temperatures [46].

The electrical output power of PV modules under real operating conditions can be estimated analytically by considering the derating factors due to the module mismatch $\left(k_{m m}\right)$ (either positive or negative power tolerance), temperature $\left(k_{\text {tem }}\right)$, the peak sun factor $\left(k_{g}\right)$, dust accumulation $\left(k_{\text {dirt }}\right)$, and ageing $\left(k_{\text {age }}\right)$. The derating factor due to the module mismatch $\left(k_{m m}\right)$ is calculated based on given power tolerance in the manufacturer datasheet [47]. On the other hand, for dust $\left(k_{d u s t}\right)$ and ageing $\left(k_{\text {age }}\right)$ factors, they are estimated based on the year of installation and manufacturing respectively. The derating factors due to temperature $\left(k_{t e m}\right)$ and solar irradiation $\left(k_{g}\right)$ significantly affect the value of voltage and current, respectively and calculated based on the following equations:

$$
k_{\text {tem }}=1+\left[\left(\frac{\delta}{100 \%}\right) \times\left(T_{m}-T_{s t c}\right)\right]
$$


where $k_{\text {temp }}$ is the derating factor due to temperature, $\delta$ is the temperature coefficient of electrical quantities $\left(\% /{ }^{\circ} \mathrm{C}\right), T_{m}$ is the module efficiency at ROC $\left({ }^{\circ} \mathrm{C}\right)$, and $T_{s t c}$ is the module temperature at STC $\left({ }^{\circ} \mathrm{C}\right)$. Note that, $\delta$ is representing $\alpha, \beta$ and $\gamma$ for power, voltage and current respectively. Based on Ross-thermal model, the module temperature can be analytically estimated using the following:

$$
T_{m}=T_{a m b}+\left[\left(\frac{N O C T-20^{\circ} \mathrm{C}}{800 \mathrm{Wm}^{-2}}\right) \times G\right]
$$

or $\quad T_{m}=T_{a m b}+T_{\text {elevated }}$

where $T_{a m b}$ is the ambient temperature $\left({ }^{\circ} \mathrm{C}\right)$, and $T_{\text {elevated }}$ is the elevated module temperature during operation. Based on Australian Standard 1995, $T_{\text {elevated }}=25{ }^{\circ} \mathrm{C}$. The derating factor due to irradiance $\left(k_{g}\right)$, can be determined as:

$$
k_{g}=\frac{G}{1000}
$$

where $k_{g}$ is the derating factor due to solar irradiation, $G$ is solar irradiance $\left(\mathrm{W} / \mathrm{m}^{2}\right)$. By combining all the derating factors, the estimated electrical outputs of a PV module at ROC $\left(P_{R O C}\right)$ can be calculated as follows:

$$
\begin{aligned}
& P_{R O C}=P_{S T C} \times k_{\text {power_derating }} \\
& K_{\text {power_derating }}=k_{m m} \times k_{\text {tem }} \times k_{g} \times k_{\text {dirt }} \times k_{\text {age }}
\end{aligned}
$$

where $P_{S T C}$ is power rated at STC and electrical efficiency is determined by the module's efficiency at STC and temperature coefficients as per the manufacturer datasheet. The effect of module temperature increment can be analysed using the following equation:

$$
\eta_{m}=\eta_{s t c}\left[1-\beta_{\text {stc }}\left(T_{\text {module }}-T_{\text {stc }}\right)\right]
$$

where $\eta_{m}$ is module efficiency under real operating conditions, $\eta_{s t c}$ is the module efficiency as per datasheet, $\beta_{\text {stc }}$ is the temperature coefficient $\left(\% /{ }^{\circ} \mathrm{C}\right), T_{\text {module }}$ is module temperature at ROC $\left({ }^{\circ} \mathrm{C}\right)$ and $T_{\text {stc }}$ is module temperature at STC $\left({ }^{\circ} \mathrm{C}\right)$. Based on IEC 61215, the difference between estimated and measured values must be less than $5 \%$ for acceptable percentage error.

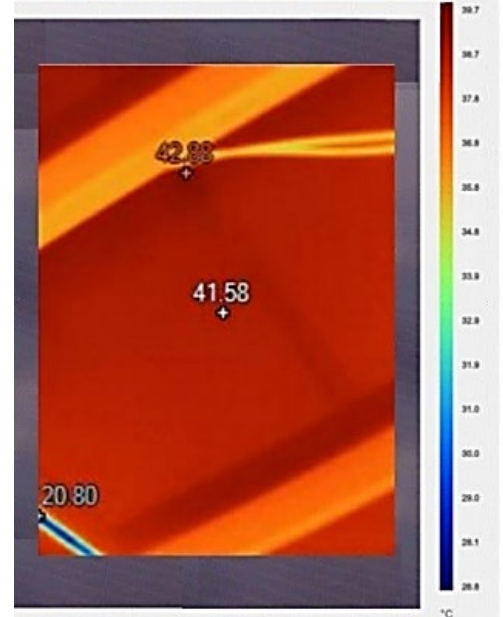

(a)

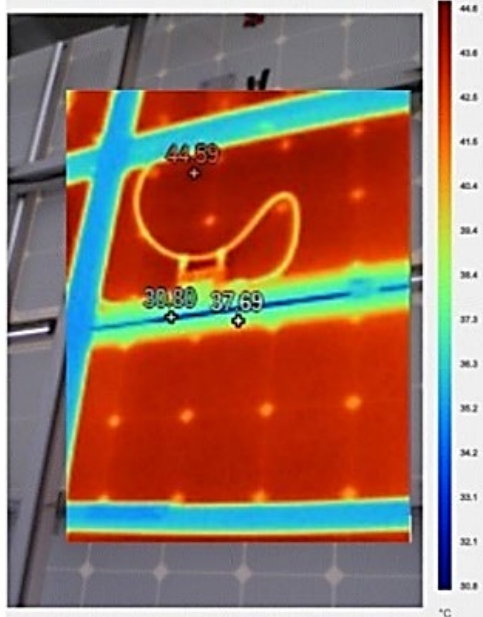

(b)

Figure 1. Thermal images of (a) thin-film and (b) monocrystalline PV module

\section{CURRENT STATE-OF-THE-ART ON PASSIVE COOLING TECHNOLOGIES}

This section discusses recent literature on passive cooling methods. The main objective is to provide a brief overview of obtaining useful information for further improvements. A detailed review of the most current passive cooling techniques for PV module is essential for further modifications of existing PV modules to improve the efficiency of electrical output. 


\subsection{Passive cooling using phase change materials}

Extensive research studies have been investigated to propose an efficient cooling technique by integrating phase change materials (PCMs). This process is known as the passive cooling method as no external powers required. It occurs during the solid-liquid phase transition when the heat produced from the PV module is absorbed in PCMs as latent heat at constant phase temperature [48].

Wongwuttanasatian et al. [19] have designed grooved tube and finned containers of the same volume $\left(3000 \mathrm{~cm}^{3}\right)$ filled with palm wax as PCM. It was observed that by introducing PCM cooling in a finned box could enhance the module efficiency by up to $9.82 \%$. This approach contributes to a $5.3 \%$ improvement in electrical efficiency. However, their study reveals the electrical efficiency of the module could be significantly enhanced if the irradiance level is more than $500 \mathrm{~W} / \mathrm{m}^{2}$, and the use of PCM is not feasible for low irradiance location.

Authors in Ref. [48] examined the performance of salt hydrate (PCM32/280) as a PCM. A polycarbonate sheet was used to fill the PCM and attached under the absorber plate. The study was conducted with PCM cooling exposed under both natural and forced convection. The PCM integration helps to improve the PV module temperature by $4.3{ }^{\circ} \mathrm{C}$ and $3.6{ }^{\circ} \mathrm{C}$ under the natural and forced cooling, respectively. The study shows that the use of PCM under natural convection outweigh forced convection.

Nada et al. [21] have reported the experimental study analysing the performances of hybrid nanoparticles and paraffin/wax insertions to reduce the module temperature. Paraffin/wax is used as the PCM, and aluminium oxide powder $\mathrm{Al}_{2} \mathrm{O}_{3}$ is used as nanoparticles aimed to enhance the thermophysical properties of the cooling medium. As a result, the PV module with the pure PCM and enhanced PCM with $2 \%$ of $\mathrm{Al}_{2} \mathrm{O}_{3}$ can reduce the module temperature by $8.1^{\circ} \mathrm{C}$ and $10.6{ }^{\circ} \mathrm{C}$ respectively. Similarly, Baygi and Sadrameli [23] have experimentally examined the use of polymer grade PCM to be incorporated as a coolant. The melting point of polyethylene glycol 1000 of nearly $40{ }^{\circ} \mathrm{C}$ seems ideally suited for this approach. Eight rectangular-shaped of aluminium containers were filled with PEG-1000 were installed at the rear side. The authors indicate that by incorporating PEG-1000, the module temperature was recorded at lower value of $47^{\circ} \mathrm{C}$ at solar noon while the electrical efficiency was enhanced up to $8 \%$.

Hachem et al. [24] have conducted an experimental study of combined PCM to regulate the module temperature. The combined PCM consists of white petroleum jelly (70\%), copper (20\%), and graphite $(10 \%)$. The experimental results indicate that the output power had been increased by up to $3 \%$ with pure PCM and 5.8\% with combined PCM.

\subsection{Passive cooling with fin heat sink}

Many researchers have contributed to the fin structured heat sink development attached at the rear side of the PV module under natural convection. Hernandez-Perez et al. [33] examined the performance enhancement of PV modules incorporating multiangular aluminium fins, which intended to increase the vortex generation by allowing multidirectional and less restrictive airflow. A numerical model was developed using ANSYS FLUENT for design optimisation in terms of fin length, material, and heat transfer. Using this heat sink method, the achieved theoretical and experimental temperature reduction of the PV module was as high as $9.4{ }^{\circ} \mathrm{C}$ and $10{ }^{\circ} \mathrm{C}$, respectively. The electrical efficiency was improved by $4 \%$ with the proposed segmented aluminium heat sink. Fatih et al. [49] analysed similar design called staggered array with ten different aluminium fin configurations of various parameters. It was observed that the energy and exergy efficiencies increased by $11.55 \%$ and $10.91 \%$, respectively.

The effect of fin thickness and fin height has been further investigated by Amr et al. [28]. They have designed and developed an array of longitudinal aluminium fins attached at the back of the PV module. The experimental set-up consists of two $250 \mathrm{~W}$ Si-poly, tested under Egyptian condition. The optimum dimensions obtained from numerical analysis consists of 10 aluminium fins with the height and thickness of $10 \mathrm{~cm}$ and $0.2 \mathrm{~cm}$, respectively. However, the authors found that the effect of fin thickness and thermal conductivity are not significant.

Elbreki et al. [50] carried out a numerical and experimental investigation on heat transfer performance of Lapping fins with planar reflectors. The results illustrated that the PV module temperature was reduced from $64.3{ }^{\circ} \mathrm{C}$ without cooling to $39.73{ }^{\circ} \mathrm{C}$ with the fin height of $200 \mathrm{~mm}$. The authors found that the fin thickness above $2 \mathrm{~mm}$ does not affect output performance of the PV module. The use of lapping fins and planar reflectors improved the efficiency of the PV module from $9.81 \%$ (without cooling) to $11.2 \%$ (with cooling fins).

Authors in Ref. [32] have undertaken an experimental analysis of a cooling PV module with porous metal foams as a fin heat sink. The metal foam $(6$ and $10 \mathrm{~mm})$ consists of a cellular structure of metal with high porosity characteristics ranging from 75 to $95 \%$ were used in this study. It was observed that the PV module temperature was improved from $49{ }^{\circ} \mathrm{C}$ to $48{ }^{\circ} \mathrm{C}$ at solar noon. The inefficient cooling was due to uneven metal foam structures that caused heat accumulation. Similarly, Cabo et al. [29] have investigated 
the passive cooling effects on a PV module energy conversion efficiency. Two fin geometries were considered in the study. The first orientation was parallel positioned L profile, and the second orientation was randomly placed and perforated aluminium fins. The experiments were performed under solar radiation between 200 to $900 \mathrm{~W} / \mathrm{m}^{2}$. The second fin geometry was observed to perform better than the first geometry. The perforated and randomly positioned fins gave better output performance by $2 \%$.

Chandra et al. [51] have designed cooling fins known as a thin flat metallic sheet (TFMS). The experimental set-up was measured under the following parameters; fin numbers ( 0 to 4$)$ and controlled solar intensity in the range of 200 to $700 \mathrm{~W} / \mathrm{m}^{2}$. It was found that the maximum thermal and electrical efficiency were recorded at $56.19 \%$ and $13.75 \%$ respectively for four numbers of fins at $0.14 \mathrm{~kg} / \mathrm{s}$ and $700 \mathrm{~W} / \mathrm{m}^{2}$ solar radiation. Such structural modification will be effectively integrated into buildings.

\subsection{Passive cooling with radiative cooling}

Radiative cooling is a method based on a high transparency atmospheric window at the wavelength range of 8-14 $\mu \mathrm{m}$ [52]. Zhao et al. [53] investigated the hybrid cooling method incorporating PV and nighttime radiative cooling. The set-up consisted of a low-density polyethylene transparent cover (TPT), PV panel, insulation material, and six copper pipes welded on the rear side of the PV module. The use of a transparent TPT layer shows promising effects for its high thermal emissivity and excellent insulation material. The average electrical efficiency evaluated at sunny days nearly reached $14.9 \%$, lower than morning and afternoon, and net radiative cooling power of $72.94 \mathrm{~W} / \mathrm{m}^{2}$. This scenario revealed the negative effect of the higher operating temperature of the solar cell. It was found that the performance of radiative cooling significantly depends on the atmospheric humidity of a specific location.

A group of researchers [35] established a thermal electric coupled model to evaluate the effectiveness of a selective spectral and radiative cooling at different ambient conditions. The top glass cover was modified such that it works as a filter to the solar wavelengths and highly emissive at the infrared spectrum known as RC emitter. The efficiency of the PV module could be improved by $4.55 \%$ for this combined cooling approaches. It was found that the efficiency could be further enhanced by at least $2-2.5 \%$ at relatively lower humidity locations around China.

Another comprehensive photonic approach has been investigated based on nocturnal radiative cooling [54]. The selective plate was designed by incorporating a $500 \mu \mathrm{m}$-thick silica as a photonic crystal structure at the front side of the solar cell. Alternatively, the rear side was layered with multilayer materials such as $\mathrm{SiO}_{2}, \mathrm{TiO}_{2}$, and $\mathrm{MgF}_{2}$. The electricity output of diurnal photovoltaic was recorded at $6.9 \%$ with an output power of $99.2 \mathrm{~W} / \mathrm{m}^{2}$. This photonic approach can be applied to any other solar cells. The various passive cooling methods discussed in this section are summarised in Table 1.

Table 1. Summary of the passive cooling methods

\begin{tabular}{|c|c|c|c|c|c|}
\hline Ref. & Cooling method & PV Technology & Year & Type of work & $\begin{array}{c}\text { Power Conversion } \\
\text { Efficiency Improvement }\end{array}$ \\
\hline [19] & PCM (palm wax) & Si-poly (20W) & 2020 & Experimental & $5.3 \%$ \\
\hline [48] & PCM (salt hydrate) & Si-mono (90W) & 2019 & Experimental & $4.3 \%$ \\
\hline [21] & $\mathrm{PCM}$ and $\mathrm{Al}_{2} \mathrm{O}_{3}$ & Si-poly (30W) & 2018 & Experimental & $5.7 \%$ \\
\hline [23] & PCM (PEG 1000) & Si-mono (40W) & 2018 & Experimental & $8.0 \%$ \\
\hline [24] & PCM (copper \& graphite) & Si-poly (30W) & 2017 & Experimental & $5.8 \%$ \\
\hline [33] & Fin heatsink (segmented) & Si-poly $(15 \mathrm{~W})$ & 2020 & Experimental \& Numerical & $10.0 \%$ \\
\hline [50] & Fin heatsink (lapping, reflector) & Si-poly (40W) & 2020 & Experimental \& Numerical & $11.2 \%$ \\
\hline [49] & Fin heatsink (staggered array) & Si-poly $(75 \mathrm{~W})$ & 2019 & Experimental & $11.5 \%$ \\
\hline [28] & Fin heatsink (longitudinal) & Si-poly (250W) & 2019 & Experimental \& Numerical & $5.0 \%$ \\
\hline$[32]$ & Fin heatsink (porous metal) & Si-poly $(75 \mathrm{~W})$ & 2018 & Experimental & $1.0 \%$ \\
\hline [29] & Fin heatsink (Perforated-L) & Si-poly $(50 \mathrm{~W})$ & 2018 & Experimental & $2.0 \%$ \\
\hline [53] & Radiative cooling (hybrid) & Si-mono (n/a) & 2019 & Experimental & $\mathrm{n} / \mathrm{a}$ \\
\hline$[35]$ & Radiative cooling (TE coupled) & Si-mono (n/a) & 2019 & Numerical & $4.55 \%$ \\
\hline [54] & Radiative cooling (photonic) & Si-mono (n/a) & 2018 & Numerical & $4.6 \%$ \\
\hline
\end{tabular}

\section{CONCLUSIONS}

This review has described three main techniques in the temperature regulation of PV modules using passive cooling techniques such as phase change materials (PCM), passive fin heatsinks, and radiative cooling. In this rapidly developing field, we expect more to appear soon. All have their merits and drawbacks, with some being better suited than others to specific environmental conditions. The most studied cooling method is the use of phase change materials (PCM). Different types of organic and inorganic PCMs have been investigated to achieve PV module cooling. However, its application is limited by its high cost, low thermal conductivity, phase-segregation, and fire safety. 
PV Cooling based on the radiative cooling concept, although sounds attractive, is only achievable under suitable atmospheric conditions. In the past few decades, nocturnal radiative cooling has been successfully demonstrated. However, to implement the concept for PV cooling application during the day under direct sunlight remains a challenge and only recently a few lab-scale applications has been proven successful, indicates its potential as a practical passive cooler during the day. Such techniques would require further research and developments since it would involve modifications of commercially available silicon solar cells.

PV cooling via fin heat sink offers enhanced heat transfer area to promote a more significant heat transfer rate from the rear surface of the PV module to the ambient mainly via natural convection. This method can be considered as the most economical in comparison to the other passive cooling techniques, technically feasible under different climatic conditions, and easy to implement or install. In the heat transfer mechanism by natural convection, the heat flow is highly dependent on the geometry of the surface (heatsinks) and its orientation. Hence, if adequately designed and computer-simulated, for example, by using a suitable computational fluid dynamics (CFD) software, the designed heat sinks may promote turbulent natural convection heat transfer that promotes better cooling rate. Besides, it is essential to optimise the surface area of the fin heat sink to achieve a balance between the rate of heat dissipation and manufacturing cost.

In summary, the passive cooling technique using fins heat sink is attractive. Therefore, there is a strong need for continuous research and development $(R \& D)$ for this type of cooling technique with more innovative design and configuration to further enhance its capacity as a reliable PV passive cooling technology.

\section{ACKNOWLEDGEMENTS}

Financial support by the UKM through research funding Skim Geran Penyelidikan Fundamental (FRGS) (FRGS/1/2019/TK07/UKM/02/4) is gratefully acknowledged.

\section{REFERENCES}

[1] N. Benadla and K. Ghaffour, "Optimising the performance of photovoltaic cells IBC ( interdigitated back contact ) by numerical simulation," International Journal of Electrical and Computer Engineering (IJECE), vol. 9, no. 6, pp. 4566-4572, 2019.

[2] M. Emam, S. Ookawara, and M. Ahmed, "Performance study and analysis of an inclined concentrated photovoltaic-phase change material system," Sol. Energy, vol. 150, pp. 229-245, 2017.

[3] J. Zhao, Z. Li, and T. Ma, "Performance analysis of a photovoltaic panel integrated with phase change material," Energy Procedia, vol. 158, pp. 1093-1098, 2019.

[4] Y. Du et al., "Evaluation of photovoltaic panel temperature in realistic scenarios," Energy Convers. Manag., vol. 108, pp. 60-67, 2016.

[5] A. H. Ali, H. S. Hamad, and A. A. Abdulrazzaq, "Performance Investigation of Grid Connected Photovoltaic System Modelling Based on MATLAB Simulation," International Journal of Electrical and Computer Engineering (IJECE), vol. 8, no. 6, pp. 4847-4854, 2018.

[6] S. Nižetić, E. Giama, and A. M. Papadopoulos, "Comprehensive analysis and general economic-environmental evaluation of cooling techniques for photovoltaic panels, Part II: Active cooling techniques," Energy Convers. Manag., vol. 155, pp. 301-323, 2018.

[7] A. Ibrahim, S. Mat, A. Fudholi, A. F. Abdullah, and K. Sopian, "Outdoor performance evaluation of building integrated photovoltaic thermal (BIVPT) solar collector with spiral flow absorber configurations," Int. J. Power Electron. Drive Syst., 2018.

[8] L. Yang, et al., "Enhanced ef fi ciency of photovoltaic panels by integrating a spray cooling system with shallow geothermal energy heat exchanger," Renewable Energy, vol. 134, pp. 970-981, 2019.

[9] H. Alizadeh, R. Ghasempour, M. B. Shafii, M. H. Ahmadi, W. M. Yan, and M. A. Nazari, "Numerical simulation of PV cooling by using single turn pulsating heat pipe," Int. J. Heat Mass Transf., vol. 127, pp. 203-208, 2018.

[10] H. Wang, J. Qu, Q. Sun, Z. Kang, and X. Han, "Thermal characteristic comparison of three-dimensional oscillating heat pipes with/without sintered copper particles inside fl at-plate evaporator for concentrating photovoltaic cooling," Appl. Therm. Eng., vol. 167, 2020.

[11] A. E. Kabeel, M. Abdelgaied, and R. Sathyamurthy, "A comprehensive investigation of the optimisation cooling technique for improving the performance of PV module with reflectors under Egyptian conditions," Sol. Energy, vol. 186 , pp. 257-263, 2019.

[12] F. Spertino, A. D'Angola, D. Enescu, P. Di Leo, G. V. Fracastoro, and R. Zaffina, "Thermal-electrical model for energy estimation of a water cooled photovoltaic module," Sol. Energy, vol. 133, pp. 119-140, 2016.

[13] S. Y. Wu, C. Chen, and L. Xiao, "Heat transfer characteristics and performance evaluation of water-cooled PV/T system with cooling channel above PV panel," Renew. Energy, vol. 125, pp. 936-946, 2018.

[14] S. Y. Wu, T. Wang, L. Xiao, and Z. G. Shen, "Effect of cooling channel position on heat transfer characteristics and thermoelectric performance of air-cooled PV/T system," Sol. Energy, vol. 108, pp. 489-500, 2019. 
[15] A. Fudholi, M. F. Musthafa, A. Ridwan, R. Yendra, and A. P. Desvina, "Energy and exergy analysis of air based photovoltaic thermal ( PVT ) collector: a review," International Journal of Electrical and Computer Engineering (IJECE), vol. 9, no. 1, pp. 109-117, 2019.

[16] U. Sajjad, M. Amer, H. M. Ali, A. Dahiya, and N. Abbas, "Cost effective cooling of photovoltaic modules to improve efficiency," Case Stud. Therm. Eng., vol. 14, pp. 100420, 2019.

[17] T. Wongwuttanasatian, T. Sarikarin, and A. Suksri, "Performance enhancement of a photovoltaic module by passive cooling using phase change material in a finned container heat sink," Sol. Energy, vol. 195, pp. 47-53, 2020.

[18] N. Choubineh, H. Jannesari, and A. Kasaeian, "Experimental study of the effect of using phase change materials on the performance of an air-cooled photovoltaic system," Renewable and Sustainable Energy Reviews, vol. 101, pp. 103-111, 2019.

[19] S. A. Nada, D. H. El-Nagar, and H. M. S. Hussein, "Improving the thermal regulation and efficiency enhancement of PCM-Integrated PV modules using nano particles," Energy Convers. Manag., vol. 166, pp. 735-743, 2018.

[20] S. Khanna, K. S. Reddy, and T. K. Mallick, "Optimization of finned solar photovoltaic phase change material (finned pv pcm) system," International Journal of Thermal Sciences, vol. 130, pp. 313-322, 2018.

[21] S. R. M. Baygi and S. M. Sadrameli, "Thermal management of photovoltaic solar cells using polyethylene glycol 1000 ( PEG1000) as a phase change material," Thermal Science and Enginee. Progress, vol. 5, pp. 405-411, 2018.

[22] F. Hachem, et al., "Improving the performance of photovoltaic cells using pure and combined phase change materials-Experiments and transient energy balance," Renew. Energy, vol. 107, pp. 567-575, 2017.

[23] J. Xie, K. F. Choo, J. Xiang, and H. M. Lee, "Characterisation of natural convection in a PCM-based heat sink with novel conductive structures," Int. Commun. Heat Mass Transf., vol. 108, 2019.

[24] T. Ma, J. Zhao, and J. Han, "A Parametric Study about the Potential to Integrate Phase Change Material into Photovoltaic Panel,” Energy Procedia, vol. 142, pp. 648-654, 2017.

[25] L. Idoko, O. Anaya-Lara, and A. McDonald, "Enhancing PV modules efficiency and power output using multiconcept cooling technique," Energy Reports, vol. 4, pp. 357-369, 2018.

[26] A. A. raheim Amr, et al., "Enhancement of photovoltaic system performance via passive cooling: Theory versus experiment," Renewable Energy, vol. 104, pp. 88-103, 2019.

[27] C. K. Gan, P. H. Tan, and S. Khalid, "System performance comparison between crystalline and thin-film technologies under different installation conditions," in CEAT 2013 - 2013 IEEE Conference on Clean Energy and Technology, 2013.

[28] I. K. Karathanassis, et al., "Experimental and numerical evaluation of an elongated plate-fin heat sink with three sections of stepwise varying channel width," Int. Journal of Heat and Mass Transfer, vol. 84, pp. 16-34, 2015.

[29] F. Selimefendigil, F. Bayrak, and H. F. Oztop, "Experimental analysis and dynamic modeling of a photovoltaic module with porous fins," Renew. Energy, vol. 125, pp. 193-205, 2018.

[30] J. G. Hernandez-Perez, et al, "A new passive PV heatsink design to reduce efficiency losses: A computational and experimental evaluation," Renew. Energy, vol. 147, pp. 1209-1220, 2020.

[31] B. Zhao, M. Hu, X. Ao, and G. Pei, "Performance analysis of enhanced radiative cooling of solar cells based on a commercial silicon photovoltaic module," Sol. Energy, vol. 176, pp. 248-255, 2018.

[32] H. Li, J. Zhao, M. Li, S. Deng, Q. An, and F. Wang, "Performance analysis of passive cooling for photovoltaic modules and estimation of energy-saving potential," Sol. Energy, vol. 181, pp. 70-82, 2019.

[33] M. Hu, B. Zhao, X. Ao, P. Zhao, Y. Su, and G. Pei, "Field investigation of a hybrid photovoltaic-photothermicradiative cooling system," Appl. Energy, vol. 231, pp. 288-300, 2018.

[34] A. Shukla, K. Kant, A. Sharma, and P. H. Biwole, "Cooling methodologies of photovoltaic module for enhancing electrical efficiency: A review,” Sol. Energy Mater. Sol. Cells, vol. 160, pp. 275-286, 2017.

[35] J. Siecker, K. Kusakana, and B. P. Numbi, "A review of solar photovoltaic systems cooling technologies," Renewable and Sustainable Energy Reviews, vol. 79, pp. 192-203, 2017.

[36] A. Saleem, et al., "The effect of environmental changes on the efficiency of the PV system," Indonesian Journal of Electrical Engineering and Computer Science (IJEECS), vol. 18, no. 1, pp. 558-564, 2019.

[37] J. Assadeg, K. Sopian, and A. Fudholi, "Performance of grid-connected solar photovoltaic power plants in the Middle East and North Africa," International Journal of Electrical and Computer Engineering (IJECE), vol. 9, no. 5, pp. 3375-3383, 2019.

[38] Y. Hishikawa, "Voltage-Dependent Temperature Coefficient of the I-V Curves of Crystalline Silicon Photovoltaic Modules," IEE J. Photovoltaics, vol. 8, no. 1, pp. 48-53, 2018.

[39] N. Shahirah, B. Rukman, A. Fudholi, I. Taslim, and M. A. Indrianti, "Overview on recent photovoltaic module cooling methods : advances PVT systems," International Journal of Electrical and Computer Engineering (IJECE), vol. 10 , no. 1, pp. 15-21, 2020.

[40] A. Fazlizan, A. Abdulmula, A. N. Amran, C. H. Lim, and K. Sopian, "Performance evaluation of maximum light detection solar tracking system in the tropics," J. Mech. Sci. Technol., 2019.

[41] S. A. Tadjer, A. Idir, and F. Chekired, "Comparative performance evaluation of four photovoltaic technologies in saharan climates of Algeria: Ghardaïa pilot station," Indonesian Journal of Electrical Engineering and Computer Science (IJEECS), vol. 18, no. 2, pp. 586-598, 2020.

[42] O. O. Ogbomo, E. H. Amalu, N. N. Ekere, and P. O. Olagbegi, "A review of photovoltaic module technologies for increased performance in tropical climate," Renew. Sustain. Energy Rev., pp. 0-1, 2016.

[43] N. Bouaziz, A. Benfdila, and A. Lakhlef, "A model for predicting photovoltaic module performances," International Journal of Power Electronics and Drive Systems (IJPEDS), vol. 10, no. 4, pp. 1914-1922, 2019. 
[44] N. Choubineh, H. Jannesari, and A. Kasaeian, "Experimental study of the effect of using phase change materials on the performance of an air-cooled photovoltaic system," Renew. Sustain. Energy Rev., vol. 101, pp. 103-111, 2019.

[45] F. Bayrak, H. F. Oztop, and F. Selimefendigil, "Effects of different fin parameters on temperature and efficiency for cooling of photovoltaic panels under natural convection," Sol. Energy, vol. 188, pp. 484-494, 2019.

[46] A. M. Elbreki, et al., "Case Studies in Thermal Engineering An innovative technique of passive cooling PV module using lapping fins and planner reflector," Case Stud. Therm. Eng., vol. 19, 2020.

[47] J. Chandra, et al., "An experimental investigation on performance analysis of air type photovoltaic thermal collector system integrated with cooling fins design," Energy Build., vol. 130, pp. 272-285, 2016.

[48] D. Zhao et al., "Development of a single-phase thermosiphon for cold collection and storage of radiative cooling," Appl. Energy, vol. 205, pp. 1260-1269, 2017.

[49] B. Zhao et al., "Performance analysis of a hybrid system combining photovoltaic and nighttime radiative cooling," Appl. Energy, vol. 252, p. 113432, 2019.

[50] B. Zhao, M. Hu, X. Ao, Q. Xuan, and G. Pei, "Comprehensive photonic approach for diurnal photovoltaic and nocturnal radiative cooling," Sol. Energy Mater. Sol. Cells, vol. 178, pp. 266-272, 2018.

[51] J. Chandra, et al., "An experimental investigation on performance analysis of air type photovoltaic thermal collector system integrated with cooling fins design," Energy Build., vol. 130, pp. 272-285, 2016.

[52] D. Zhao et al., "Development of a single-phase thermosiphon for cold collection and storage of radiative cooling," Appl. Energy, 2017.

[53] B. Zhao et al., "Performance analysis of a hybrid system combining photovoltaic and nighttime radiative cooling," Appl. Energy, vol. 252, no. January, 2019.

[54] B. Zhao, M. Hu, X. Ao, Q. Xuan, and G. Pei, "Comprehensive photonic approach for diurnal photovoltaic and nocturnal radiative cooling," Sol. Energy Mater. Sol. Cells, vol. 178, no. Oct 2017, pp. 266-272, 2018

\section{BIOGRAPHIES OF AUTHORS}
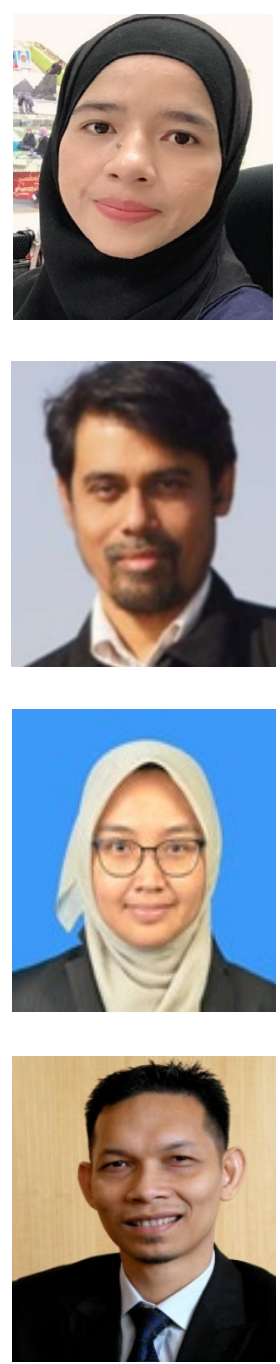

Ms Emy Zairah Ahmad graduated with MEng in Electrical Engineering from The University of Sheffield, UK, in 2009 and the MSc in Solar Technology from TU Berlin, Germany, in 2012. Currently, she is focusing the research on thermal management of photovoltaic.

Prof Dato' Dr Kamaruzzaman Sopian graduated with the BS Mechanical Engineering from the University of Wisconsin-Madison in 1985, the MS in the Energy Resources University of Pittsburgh in 1989 and $\mathrm{PhD}$ in Mechanical Engineering from the Dorgan Solar Laboratory, the University of Miami at Coral Gables in 1997. He has been involved in the field of renewable energy for more than 25-years.

Dr. Hasila graduated with the BSc in Physics from the University of Machester UK in 2008, and $\mathrm{PhD}$ in Science focusing on Solar Energy Technology from Universiti Teknologi Mara (UiTM) Perlis, Malaysia in 2016.

Dr. Ahmad Fazlizan Abdullah obtained his B.Eng. in Mechanical Engineering from Universiti Teknologi Malaysia (UTM) in 2006, M.Eng. from University of Malaya (UM) in 2012 and PhD in Renewable Energy also from UM in 2016. 


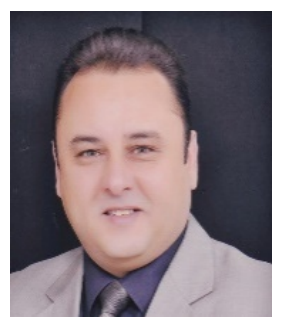

Dr. Abdel Naser graduated with the BSc in Electrical and Electronic Engineering from the University of Benghazi Libya in 1992, and PhD in Renewable Energy from Universiti Kebangsaan Malaysia, Malaysia in 2018.

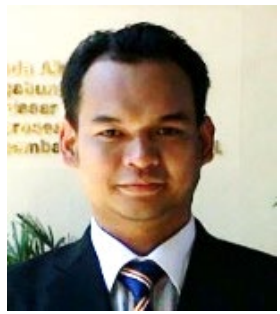

Ag Sufiyan Abd Hamid graduated with the B.Sc Nuclear Science from the Universiti Kebangsaan Malaysia in 2007, the M.Sc Energy Technology in 2009 from the same university. Currently, his research focuses on solar energy and solar drying. He has been involved in the field of renewable energy for more than 10 -years.

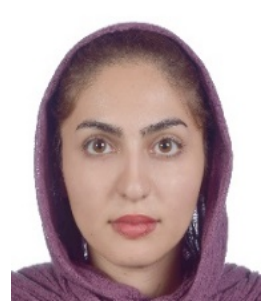

Shirin Rostami graduated with the BS in Atomic Physics from the Shiraz University, Iran in 2010, the MS in Nuclear Physics from the Persian Gulf University, Iran in 2013 and MS in Applied Physics from the Universiti Kebangsaan Malaysia in 2018. Currently, her research focuses on solar thermal systems.

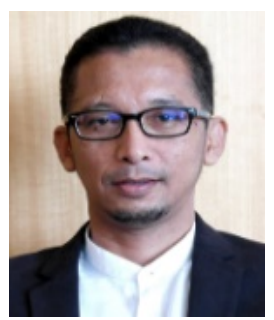

Dr. Adnan Ibrahim holds a Degree (Hons) in Manufacturing Systems Engineering from the University of Portsmouth, the United Kingdom in 2000, Master of Science in Integrated Product Development from University of Strathclyde, the United Kingdom in 2002 and Doctor of Philosophy in Renewable Energy from Universiti Kebangsaan Malaysia in 2012. 